\title{
2-Aminobenzothiazole degradation by free and Ca-alginate immobilized cells of Rhodococcus rhodochrous
}

\author{
Charlène Chorao ${ }^{\mathrm{a}, \mathrm{b}}$, Franck Charmantray ${ }^{\mathrm{a}}$, Pascale Besse-Hoggan ${ }^{\mathrm{a}}$, Martine Sancelme ${ }^{\mathrm{a}}$, Angela Cincilei ${ }^{\mathrm{c}}$, \\ Mounir Traïkia ${ }^{\mathrm{a}}$, Gilles Mailhot ${ }^{\mathrm{b}}$ and Anne-Marie Delort ${ }^{\mathrm{a}}$ \\ ${ }^{\text {a} L a b o r a t o i r e ~ d e ~ S y n t h e ̀ s e ~ E t ~ E t u d e ~ d e ~ S y s t e ̀ m e s ~ a ̀ ~ I n t e ́ r e ̂ t ~ B i o l o g i q u e, ~ U M R ~} 6504$ CNRS, Université Blaise \\ Pascal, 63177 Aubière Cedex, France \\ ${ }^{\mathrm{b}}$ Laboratoire de Photochimie Moléculaire et Macromoléculaire, UMR 6505 CNRS, Université Blaise \\ Pascal, 63177 Aubière Cedex, France \\ ${ }^{c}$ Institute of Microbiology and Biotechnology, Academy of Sciences of Moldova, Chisinau, md-2028, \\ Republic of Moldova
}

\begin{abstract}
2-Aminobenzothiazole (ABT) degradation was investigated using free and immobilized systems during photodegradation under solar light in the presence of Fe(III)-nitrilotriacetic acid (FeNTA), biodegradation by Rhodococcus rhodochrous, and during combined conditions. Ca-alginate hydrogel was chosen as a model matrix and some complementary studies were required to characterize this new system. $R$. rhodochrous metabolism in this type of environment was monitored by NMR spectroscopy. Neither change in intracellular $\mathrm{pH}$ values nor in ATP concentrations was observed by in vivo ${ }^{31} \mathrm{P}$ NMR, showing that no metabolic modification occurred between free and immobilized cells. ${ }^{1} \mathrm{H}$ NMR demonstrated that alginate was not used as carbon source by $R$. rhodochrous. After establishing the pre-treatment protocol by SPE to eliminate solubilised alginate, ABT adsorption on beads and degradation were studied. The same pathways of transformation were observed in suspended and immobilized cell systems. Considering the ABT adsorption phenomenon on alginate beads (8\%), the efficiency of the two systems was found to be comparable although the degradation rate was slightly lower with immobilized cells. The most important result was the finding that the positive effect of FeNTA on ABT degradation with immobilized cells was similar to that observed previously with free cells. All these results show that mechanisms observed with free cells can be extrapolated to entrapped cells, i.e. under conditions much closer to those usually encountered in the environment.
\end{abstract}

Keywords: Photodegradation; Biodegradation; ${ }^{31} \mathrm{P}$ NMR; Benzothiazole; FeNTA; Rhodococcus rhodochrous

\section{Introduction}

Benzothiazoles belong to an extensive family of synthetic compounds. Their skeleton is constituted by fused benzene and thiazole rings. Benzothiazoles are used in various fields e.g. in the tire industry as catalysts in vulcanization processes (Ghosh et al., 2003), as medicines for amyotrophic lateral sclerosis ([Bryson et al., 1996] and [Lacomblez et al., 1996]) and cancer chemotherapeutics (Dubey et al., 2006), as pesticides/biocides (Brownlee et al., 1992) and in the manufacture of azo-dyes (Gaja and Knapp, 1997). As a consequence of their large range of applications, these compounds are often found in the aquatic environment ([Kloepfer et al., 2004], [Kloepfer et al., 2005], [Reemtsma et al., 2006] and [De Wever et al., 2007]). Some of these molecules show toxic effects towards microorganisms, animals or humans. Therefore, it is important to investigate the mechanisms involved in the photo and biodegradation processes of such compounds in the environment.

First studies of biodegradation reported the degradation of benzothiazole-2-sulfonic acid by activated sludges (Mainprize et al., 1976). Some years later, several strains of Rhodococcus able to degrade certain benzothiazoles were isolated ([Gaja and Knapp, 1997], [De Wever et al., 1997] and [De Wever et al., 1998]). Biodegradation pathways of benzothiazole, 2-hydroxybenzothiazole and 2-mercaptobenzothiazole have been elucidated with these Rhodococcus strains ([Besse et al., 2001], [Haroune et al., 2002] and [Haroune et al., 2004]). In a recent paper, Bunescu et al. (2008a) investigated in detail the degradation pathways of 2-aminobenzothiazole (ABT), a compound used as reagent in azo-dye manufactories. They tested various conditions that could occur in the environment: (1) direct photodegradation under sunlight and photo-induced degradation in the presence of Fe(III)-nitrilotriacetic acid (FeNTA). This complex is 
usually used as a model of natural organic matter complexes of iron, (2) biodegradation by Rhodococcus rhodochrous cells, (3) two combined conditions, $R$. rhodochrous cells and FeNTA with or without irradiation. Direct photolysis under sunlight did not show any degradation of ABT since this molecule does not absorb in the solar spectrum, but the addition of FeNTA complex led to the transformation of ABT into 2-amino-6-hydroxybenzothiazole (6OH-ABT) and 2-amino-4-hydroxybenzothiazole (4OHABT) (Scheme 1). The biodegradation process led to the accumulation of $6 \mathrm{OH}-\mathrm{ABT}$, while the combined processes (biodegradation in the presence of FeNTA with or without exposure to sunlight) produced $6 \mathrm{OH}-\mathrm{ABT}$ and $4 \mathrm{OH}-\mathrm{ABT}$. Apart from the identification of the pathways involved in these different ABT degradation processes, Bunescu et al. (2008a) showed a very important feature: the presence of FeNTA, even in the absence of light, improved dramatically the rate of ABT biodegradation. Indeed $99 \%$ of ABT was degraded after $25 \mathrm{~h}$ in the combined systems while $37 \%$ and $26 \%$ of ABT were photo- and biodegraded after $125 \mathrm{~h}$, respectively. In order to understand better which mechanisms were responsible for this improvement of ABT degradation rate, the fate of FeNTA was investigated (Bunescu et al., 2008b). It was shown that FeNTA was transported and biotransformed inside the cell and/or phototransformed in the presence of sunlight (Bunescu et al., 2008b). The same products were obtained during the photo- and biodegradation processes of FeNTA, including IDA (iminodiacetic acid), glycine and formate, probably because they both involve oxidoreduction mechanisms. Photochemistry of FeNTA led to the production of radicals that activated the degradation of ABT. The intracellular Fe(II) resulting from the enzymatic reduction of Fe(III) was likely to activate degradation enzymes (dioxygenases) that contain iron in their active site and therefore increased the biodegradation rate of ABT.

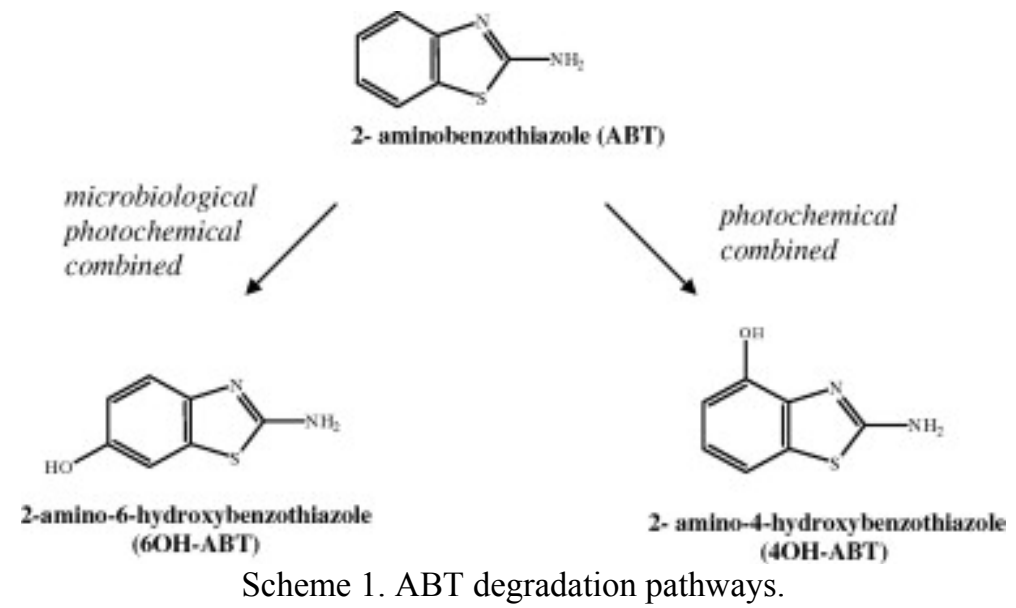

These unexpected results and mechanisms concerning the biodegradation of ABT in the presence of FeNTA (with or without irradiation) were observed with suspensions of free $R$. rhodochrous cells. However, microorganisms involved in biodegradation mechanisms are not usually found as free cells. They can be naturally entrapped or attached to matrices and form biofilms in natural waters because of extracellular polymers that they secrete themselves, or aggregates such as flocks in water treatment plants. The immobilization can also be artificial for various biotechnology applications (Junter and Jouenne, 2004). It thus appeared very important to investigate transformation processes under conditions closer to environmental ones, i.e. with cells entrapped in a matrix to see whether the same mechanisms occurred as those with free cells.

In this context, the main objective of this work was to compare ABT degradation by free and immobilized cell (IC) systems during various transformation processes: photodegradation in the presence of FeNTA, biodegradation by $R$. rhodochrous and during combined processes. More precisely, the aims were (1) to compare degradation pathways and efficiencies between free and immobilized cells, (2) to investigate whether the FeNTA complex still stimulated ABT degradation in the IC system and whether the mechanisms observed with free cells could be extrapolated to other physiological conditions involving matrix entrapped cells, much closer to environmental conditions. Ca-alginate hydrogel was chosen as a model matrix because many papers describe the entrapment of Rhodococcus cells with alginate and especially when rhodococci degrade organic pollutants (e.g. [Pai et al., 1995], [Mukerjee-Dhar et al., 1998] and [Naito et al., 2001]). Complementary studies were carried out to characterize this new system: (i) NMR study of $R$. rhodochrous metabolism in such an environment, (ii) adsorption measurements of $\mathrm{ABT}$ and FeNTA on alginate beads. In addition the set-up of a pre-treatment protocol to eliminate 
dissolved alginate from incubation media was necessary in order to monitor $\mathrm{ABT}$ and the degradation products by HPLC.

\section{Materials and methods}

\subsection{Chemicals}

2-Aminobenzothiazole (97\%), hydroxylamine hydrochloride (99\%), 3-(2-pyridyl)-5,6-diphenyl-1,2,4triazine-4,4'-disulfonic acid sodium salt (ferrocine, 97\%) and Fe(III) perchlorate nonahydrate (99\%) were purchased from Aldrich. Nitrilotriacetic acid (>99.5\%) and methylenediphosphonic acid (MDP) ( $\geqslant 99 \%)$ were purchased from Fluka, 1,10-phenanthroline ( $>99.5 \%)$ from Riedel-de-Haën, tetradeuterated sodium trimethylsilylpropionate $\left(\mathrm{TSPd}_{4}\right)$ from Eurisotop, sodium acetate $(>99 \%)$ and ammonium acetate $(>99 \%)$ from Merck, ammonia, hydrochloric acid, sulfuric acid and HEPES from Acros and alginic acid (polymannuronic acid) sodium salt (low viscosity: $40-90 \mathrm{mPa}$ in $1 \%$ aqueous solution) from Lancaster. 2-Amino-6-hydroxybenzothiazole and 2-amino-4-hydroxybenzothiazole were synthesized in the laboratory (Bunescu et al., 2008a).

\subsection{Preparation of FeNTA solution}

A 2 mM FeNTA solution was prepared in Volvic ${ }^{\circledR}$ mineral water. NTA was completely dissolved in $\mathrm{NaOH}(1 \mathrm{M})$ and $\mathrm{pH}$ was adjusted to 4.0. A solution of iron perchlorate was then added, in stoichiometric proportions, to the NTA solution. The solution obtained was protected from light, stirred for one hour and then stocked at $4{ }^{\circ} \mathrm{C}$. Perchlorate was used as a non-photosensitive and non-oxidant counter-anion rather than chlorate anion that might contribute to the oxidation of benzothiazoles. A UV-visible spectrum was recorded to check that the complete complexation of iron was completed (FeNTA $\varepsilon_{296 \mathrm{~nm}}=3300 \mathrm{M}^{-1} \mathrm{~cm}^{-1}$ ). Solution was stored at $\mathrm{pH} 4.0$ for better stability. $\mathrm{pH}$ was then adjusted to 7.0 just before the experiment.

\subsection{Photobioreactor}

The photobioreactor was equipped with 7 TLD Philips $15 \mathrm{~W}$ fluorescent tubes emitting within the wavelength range $\lambda=300-500 \mathrm{~nm}$ with a maximum emission at $360 \mathrm{~nm}$ which corresponds to part of the solar spectrum. The temperature was kept at $27^{\circ} \mathrm{C}$ and a stirring system ensured the oxygenation and homogeneity of the media. The polychromatic photon flux was measured and controlled for each position with a Testo 545 luxmeter.

\subsection{Growth conditions}

R. rhodochrous OBT18 was grown in $100 \mathrm{~mL}$ portions of Trypcase-soy broth (bioMérieux, Marcy l'Etoile, France) in $500 \mathrm{~mL}$ Erlenmeyer flasks incubated at $27^{\circ} \mathrm{C}, 200 \mathrm{rpm}$ and for $24 \mathrm{~h} .300 \mathrm{~mL}$ of the culture medium $\left(\approx 3 \mathrm{~g}\right.$ of wet-weight cells) were then centrifuged at $8000 \mathrm{rpm}$, at $4{ }^{\circ} \mathrm{C}$ and for $15 \mathrm{~min}$. The bacterial pellet was first washed with $\mathrm{NaCl}(8 \%)$ and then with Volvic ${ }^{\circledR}$ mineral water.

\subsection{Alginate bead preparation}

Alginate $(0.75 \mathrm{~g})$ was added to $10 \mathrm{~mL}$ of distilled water and autoclaved $\left(20 \mathrm{~min}\right.$ at $\left.121{ }^{\circ} \mathrm{C}\right)$ to make the dissolution easier. A solution containing $8 \mathrm{~mL}$ of $8 \% \mathrm{NaCl}$ and $3 \mathrm{~g}$ of cells was then added to the alginate preparation and the mixture was stirred, slowly to avoid air bubbles, for $15 \mathrm{~min}$. This mixture was extruded dropwise through a needle $(\varnothing 0.8 \mathrm{~mm})$ to a $0.2 \mathrm{M} \mathrm{CaCl}_{2}$ solution where they gelled instantaneously giving spherical entrapment beads. To ensure better stability, the beads were stored at $4{ }^{\circ} \mathrm{C}$ for $90 \mathrm{~min}$. They were washed twice with $\mathrm{NaCl}(8 \%)$ and then stored at $4{ }^{\circ} \mathrm{C}$ in $100 \mathrm{~mL}$ of $\mathrm{NaCl}$ $(8 \%)$. The Ca-alginate beads had a diameter of $3 \mathrm{~mm}$ and contained $\approx 10^{7}$ bacteria each. The same protocol was used for the controls without cells.

\subsection{Incubation with ABT}

Cells $(3 \mathrm{~g})$ were incubated with $100 \mathrm{~mL}$ of ABT $(0.5 \mathrm{mM})$ and/or FeNTA $(1 \mathrm{mM})$ in transparent or opaque $500 \mathrm{~mL}$ flasks depending on whether or not irradiation of the solution was required. Stocked solutions of ABT and FeNTA twice concentrated were prepared in Volvic ${ }^{\circledR}$ mineral water, in order to work with water of constant composition. The $\mathrm{pH}$ of the FeNTA solution was adjusted to 7.0 just before 
the experiment. Samples $(2 \times 1 \mathrm{~mL})$ were regularly taken from each flask, centrifuged at $12500 \mathrm{rpm}$ for $3 \mathrm{~min}$ and then frozen till analyses.

\subsection{Incubation with alginate}

Cells $(3 \mathrm{~g})$ were incubated with $100 \mathrm{~mL}$ of a $400 \mathrm{mg} \mathrm{L}^{-1}$ alginate solution. Samples of $5 \mathrm{~mL}$ were taken every $24 \mathrm{~h}$ and freeze-dried after centrifugation. The residue was dissolved in $500 \mu \mathrm{L}$ of $\mathrm{D}_{2} \mathrm{O}$, freezedried again and dissolved in $500 \mu \mathrm{L}$ of $\mathrm{D}_{2} \mathrm{O}$ to perform ${ }^{1} \mathrm{H}$ NMR analyses.

\subsection{Analytical techniques}

All the experimental points are a mean value of three samplings. Moreover each experiment was repeated at least twice. The experimental error for the ABT and iron measurements was estimated to be less than $8 \%$.

\subsubsection{HPLC}

Analyses were carried out with an Agilent 1100 series apparatus fitted with a DAD detector and driven by Chemstation software. Analyses were performed in isocratic mode at $25{ }^{\circ} \mathrm{C}$ with a reversed phase endcapped column (Zorbax Eclipse XDB-C18, Agilent, $250 \mathrm{~mm} \times 4.6 \mathrm{~mm}, 5 \mu \mathrm{m}, 80 \AA$ ). The mobile phase was composed of acetonitrile and Milli-Q water in $25 / 75$ ratio with a flow rate of $1 \mathrm{~mL} \mathrm{~min}^{-1}$. Spectra were recorded between $\lambda=200$ and $400 \mathrm{~nm}$, the detection wavelength was $\lambda=265 \mathrm{~nm}$. Ten microliters of the sample were injected with a 15 min run time.

\subsubsection{Iron analyses}

Iron analyses were performed with a liquid handling robot, Freedom Evo from TECAN ${ }^{\circledR}$, coupled with a Safire $^{2}$ UV-visible detector. Ninety-six well plates were used for the assays.

\subsubsection{Total iron titration}

$\mathrm{Fe}(\mathrm{III})$ species were reduced in $\mathrm{Fe}(\mathrm{II})$ with hydroxylamine chlorhydrate $(3 \mathrm{M}$ in $30 \%$ of hydrochloric acid). Addition of ferrocine $(0.02 \mathrm{mM}$ in Milli-Q) led to the formation of a strong colored magenta complex with $\mathrm{Fe}(\mathrm{II})$ stable at basic $\mathrm{pH}$ (Stookey, 1970). For the titration of a sample, $10 \mu \mathrm{L}$ of supernatant was reduced with $15 \mu \mathrm{L}$ of hydroxylamine chlorhydrate, $150 \mu \mathrm{L}$ of Milli-Q water was then added and the solution was stirred for $1 \mathrm{~min}$ at $20 \mathrm{~Hz}$. The addition of $15 \mu \mathrm{L}$ of ferrocine was followed by the addition of $30 \mu \mathrm{L}$ of ammonium acetate buffer ( $5 \mathrm{mM}$ in ammonia $25 \%)$ and $30 \mu \mathrm{L}$ of Milli-Q water. Absorbance was recorded at $\lambda=562 \mathrm{~nm}$, corresponding to the maximal absorption of the magenta complex.

\subsubsection{SPE treatment}

The incubation medium with alginate beads contained dissolved alginate which was removed by Solid Phase Extraction (SPE) treatment using Oasis ${ }^{\circledR}$ HLB cartridges (Waters, $30 \mu \mathrm{m}, 10 \mathrm{mg}, 1 \mathrm{~mL}$ ) (Fig. 1A). The work-up was performed with the TECAN ${ }^{\circledR}$ liquid handling robot using 96-cartridge plates. The phase was conditioned with $350 \mu \mathrm{L}$ of methanol and washed with $700 \mu \mathrm{L}$ of Milli-Q water. The sample $(200 \mu \mathrm{L})$ was loaded and the phase was washed with $700 \mu \mathrm{L}$ of Milli-Q water. The compounds were eluted with $200 \mu \mathrm{L}$ of acetonitrile and $600 \mu \mathrm{L}$ of Milli-Q water were added to reproduce the chromatographic conditions (mobile phase: acetonitrile/water in 25/75 ratio). 
A

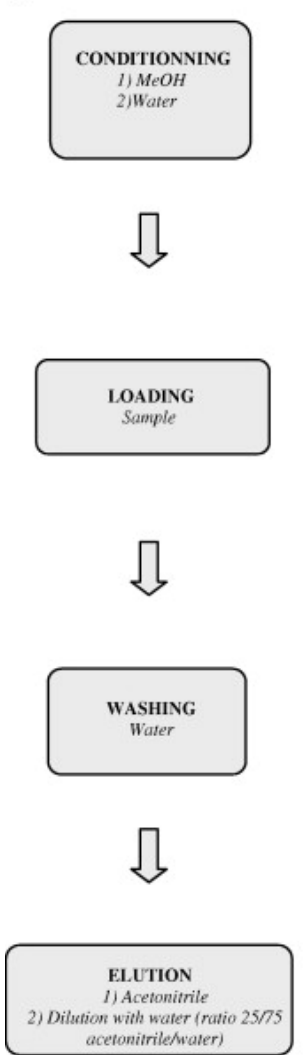

B residual water signal
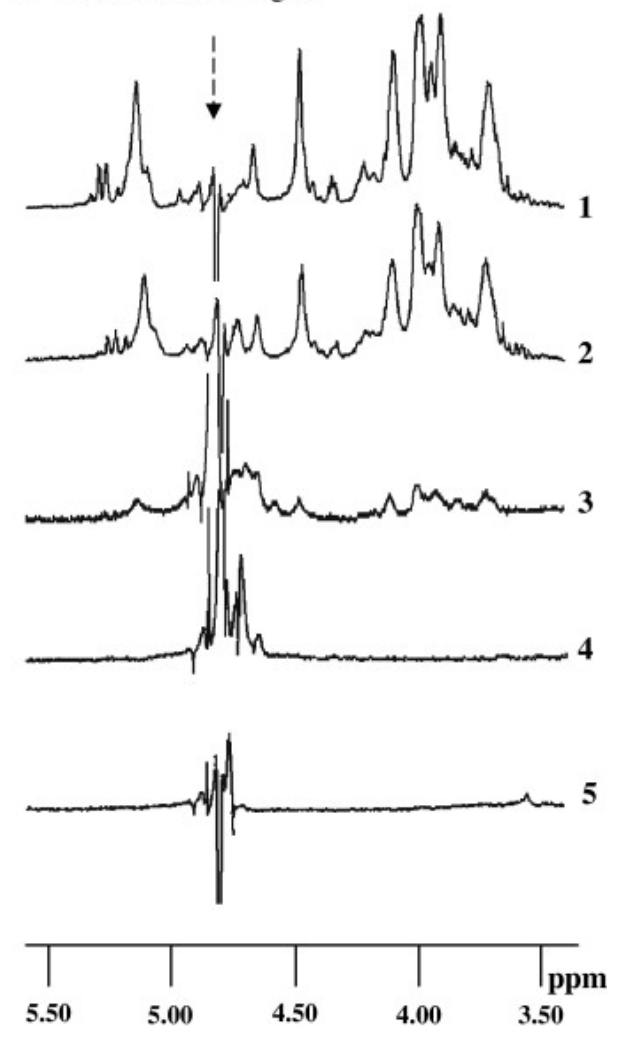

Fig. 1. Alginate removal by SPE method. (A) Extraction scheme, (B) ${ }^{1} \mathrm{H}$ NMR spectra (sugar zone), 1: before SPE treatment, 2: after loading, 3: after the 1st wash, 4: after the 2nd wash, 5: after elution.

\subsection{5. ${ }^{1}$ H NMR spectroscopy for study of the SPE treatment}

The spectrometer used was a Bruker Avance 500 equipped with a $5 \mathrm{~mm}$ triple-tuned ${ }^{1} \mathrm{H}-{ }^{13} \mathrm{C}-{ }^{15} \mathrm{~N}$ probe fitted with a z-gradient coil. Water resonance was suppressed by low presaturation method. $\mathrm{TSPd}_{4}$ $(5 \mathrm{mM})$ dissolved in $\mathrm{D}_{2} \mathrm{O}$ was used as internal reference. Acquisition parameters: number of scans: 128; impulsion time: $6.3 \mu \mathrm{s}$; relaxation delay: $5 \mathrm{~s}$; acquisition time: $4.67 \mathrm{~s}$; spectral window: $7002 \mathrm{~Hz}$; data points: 65 536. Spectra were treated with Topspin version 2.0. For the preparation of samples, $60 \mu \mathrm{L}$ of $\mathrm{TSPd}_{4}$ solution in $\mathrm{D}_{2} \mathrm{O}(5 \mathrm{mM})$ was added to $540 \mu \mathrm{L}$ of the supernatant.

\subsection{6. ${ }^{1} \mathrm{H}$ NMR spectroscopy for study of the alginate metabolism by Rhodococcus rhodochrous}

The spectrometer used was a Varian $600 \mathrm{MHz}$ UNITY INOVA 600 NB equipped with a $5 \mathrm{~mm}$ multinuclear probe with inverse detection and $5 \mathrm{~mm}{ }^{1} \mathrm{H}-{ }^{13} \mathrm{C}-{ }^{15} \mathrm{~N}-\mathrm{PFG}$ Triple Res IDTG600-5 with zgradients in $\mathrm{D}_{2} \mathrm{O}$ using $\mathrm{TSPd}_{4}$ as internal standard. Water resonance was suppressed by standard sequence PRESAT. Spectra were processed with Topspin version 2.0.

\subsubsection{In vivo ${ }^{31} \mathrm{P}$ NMR spectroscopy}

The spectrometer used was a Bruker Avance 500 equipped with a $10 \mathrm{~mm}$ Broadband probe. Methylene diphosphonic acid $(0.25 \mathrm{mM})$ in $100 \mathrm{mM}$ Hepes buffer $\mathrm{pH} 7.5$, contained in an in situ capillary was used as an internal reference to calibrate chemical shifts $\left(16.38 \mathrm{ppm}\right.$ relative to $85 \% \mathrm{H}_{3} \mathrm{PO}_{4}(0 \mathrm{ppm})$ ). Incubation medium was composed of only Volvic ${ }^{\circledR}$ Water containing $10 \% \mathrm{D}_{2} \mathrm{O}$. Spectra were recorded with inverse-gated ${ }^{1} \mathrm{H}$ decoupling (WALTZ16 sequence). Acquisitions parameters: number of scans: 25400 (corresponding to $2 \mathrm{~h}$ acquisition for each spectrum); $90^{\circ}$ pulse time: $10 \mu \mathrm{s}$; relaxation delay: $0.05 \mathrm{~s}$; acquisition time: $0.2 \mathrm{~s}$; spectral window: $11160 \mathrm{~Hz}$; data points: $4 \mathrm{~K}$. Spectra were processed with Topspin version 2.0.

\subsubsection{Perfusion system}

${ }^{31} \mathrm{P}$ NMR experiments were performed in vivo using a perfusion system described in Fig. 2 . $R$. rhodochrous cells were perfused with Volvic ${ }^{\circledR}$ water saturated with oxygen. The perfusion rate (flow rate of $20 \mathrm{~mL} \mathrm{~min}^{-1}$ ) was controlled by a peristaltic pump. Capillary containing MDP as reference was 
inserted in the center of the tube. When experiments were performed with alginate immobilized bacteria, the beads were placed in the analysis area. Bacteria in suspension circulated continuously in the system. Temperature was regulated at $27^{\circ} \mathrm{C}$.

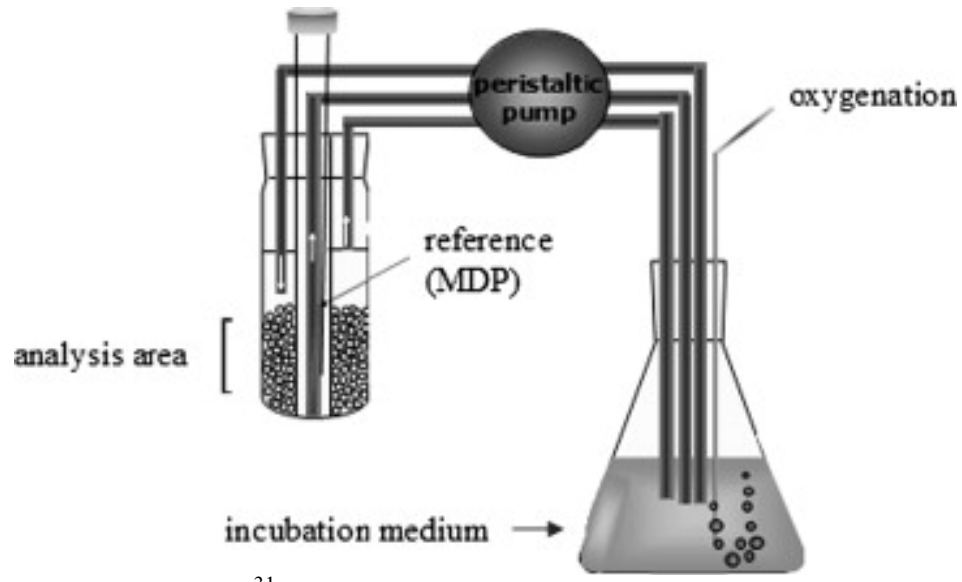

Fig. 2. Perfusion set-up to perform in vivo ${ }^{31} \mathrm{P}$ NMR studies. Rhodococcus rhodochrous cells are perfused with oxygen saturated Volvic ${ }^{\circledR}$ water from a central reservoir. The perfusion rate (flow rate of $20 \mathrm{~mL} \mathrm{~min}^{-1}$ ) is controlled by a peristaltic pump. Capillary containing MDP as reference is inserted in the center of the tube. When bacteria are immobilized in alginate beads, the beads are placed in the measurement area; when bacteria are free, they circulate continuously in the system.

Temperature is regulated at $27^{\circ} \mathrm{C}$.

\section{Results}

\subsection{Entrapment of Rhodococcus rhodochrous in Ca-alginate beads}

\subsubsection{Metabolic status of Rhodococcus rhodochrous cells entrapped in alginate beads}

The energetic metabolic status of Rhodococcus rhodochrous cells entrapped in Ca-alginate beads was compared to that of free cells by in vivo ${ }^{31} \mathrm{P}$ NMR (Grivet and Delort, 2008). The ${ }^{31} \mathrm{P}$ NMR spectra collected for immobilized and free cells (Fig. 3A and B, respectively) showed different phosphorylated metabolites that were identified by comparison with the literature (Lohmeier-Vogel et al., 2004): $\alpha$-ATP $(\delta=-10.6 \mathrm{ppm}), \beta$-ATP $(\delta=-19.1 \mathrm{ppm}), \gamma$-ATP $(\delta=-5.4 \mathrm{ppm}), \beta$-ADP $(\delta$ no precisely determined $), \mathrm{Pi}$ $(\delta=2.2 \mathrm{ppm})$, sugar phosphates $(\delta=$ no precisely determined $), \alpha$-UDPG and NAD(P)H $(\delta=-11.0 \mathrm{ppm})$, $\beta$-UDPG signals $(\delta=-12.5 \mathrm{ppm})$. Whatever the cell system studied, these metabolic markers presented the same pattern or abundance. In particular, intracellular pHs determined from Pi chemical shifts were similar ( $\mathrm{pH}$ 6.9) and ATP concentrations determined from the integral of $\beta$-ATP signals were the same. These experiments clearly show that encapsulation in alginate beads does not modify the energetic status of Rhodococcus cells.
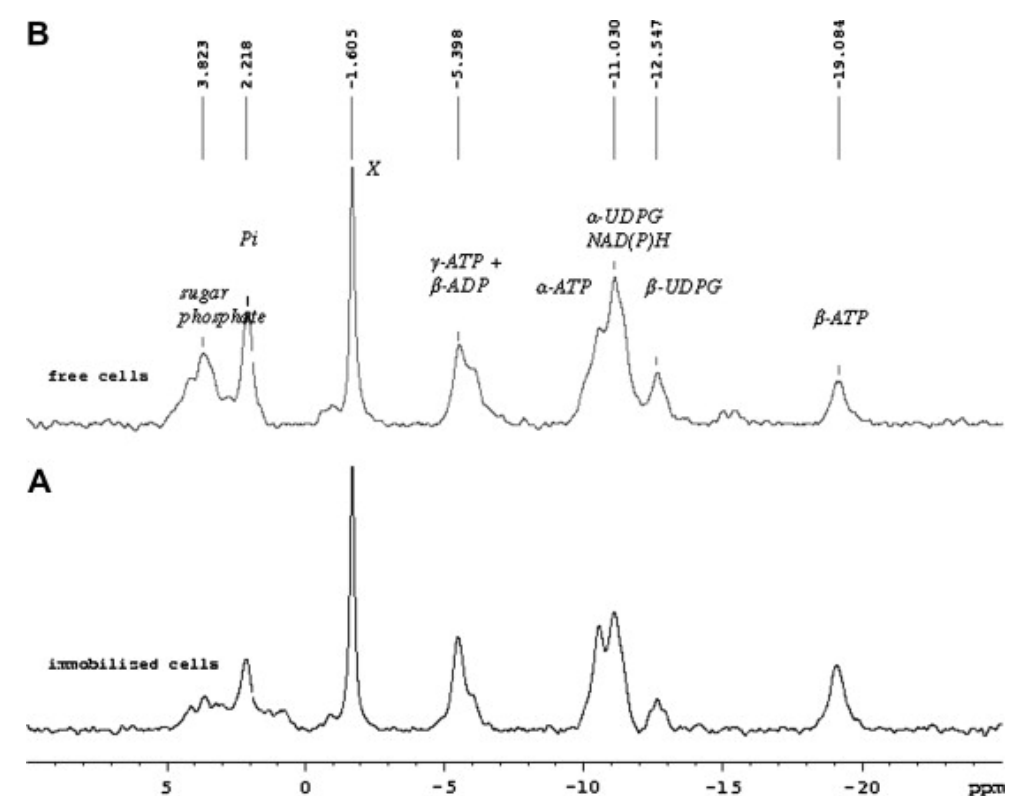

Fig. $3 .{ }^{31} \mathrm{P}$ NMR spectra acquired in vivo on immobilized (A) and suspended (B) cell system. X unidentified metabolite. 


\subsubsection{Alginate degradation by Rhodococcus rhodochrous}

Alginate is a potential carbon source for bacteria (Kitamikado et al., 1992); therefore the metabolism of Rhodococcus cells towards alginate was investigated. Rhodococcus cells in suspension were incubated with alginate in aqueous medium. The incubation was monitored during 9 days by in situ ${ }^{1} \mathrm{H}$ NMR performed directly on the incubation medium without purification. ${ }^{1} \mathrm{H}$ NMR signals corresponding to the sugar moieties of alginate did not change with time thus proving that $R$. rhodochrous does not use alginate as a carbon source (Supplementary material Fig. 1).

\subsubsection{Removal of alginate from the incubation media}

Mechanical stirring of alginate beads in water medium leads to partial dissolution of alginate in the medium with time. The HPLC column can be blocked by its presence so its removal is essential to complete further analysis. Its elimination was achieved by a pre-treatment based on Solid Phase Extraction (SPE). After several phase tests, the Oasis ${ }^{\circledR}$ HLB cartridge (Waters) was chosen. Its solid phase is composed of two polymers: a lipophilic and a hydrophilic monomer, a balance which enables the retention of hydrophobic and non-charged compounds. The alginate removal was controlled by ${ }^{1} \mathrm{H}$ NMR at each step of the SPE treatment (Fig. 1B). The ${ }^{1} \mathrm{H}$ NMR spectrum recorded before treatment of the supernatant showed the presence of alginate signals in the range between 3.50 and $5.30 \mathrm{ppm}$ (Fig. 1B, spectrum 1). The spectrum of the solution harvested after loading (Fig. 1B, spectrum 2) clearly showed the presence of alginate with a recovery rate of $80 \%$. The spectrum of the first washing solution loading (Fig. 1B, spectrum 3) showed a recovery rate of $10 \%$ but the spectrum of the second washing solution loading (Fig. 1B, spectrum 4) did not display any alginate signals. These results show that one washing step is necessary and that a second one is preferable to ensure complete removal of the polysaccharide. The spectrum of the solution after elution (Fig. 1B, spectrum 5) did not show any peaks corresponding to alginate. Therefore this SPE protocol is very efficient for alginate removal from the samples. To ensure a quantitative recovery of the compounds studied, the protocol was applied to pure solutions of various concentrations of ABT and its metabolite $6 \mathrm{OH}-\mathrm{ABT}(0.10,0.125,0.25$ and $0.5 \mathrm{mM})$ : $\mathrm{ABT}$ and $6 \mathrm{OH}-$ ABT recovery rates were found to be $100 \%$ and $94 \%$, respectively after SPE treatment.

\subsubsection{Adsorption on alginate beads}

Because alginate beads are macromolecular structures with cavities and because alginate displays alcohol and carboxylic acid functions, this material might adsorb ABT and FeNTA and therefore mislead the interpretation of quantitative data concerning degradation processes in the presence of alginate. Experiments were performed in the presence of alginate beads which did not contain bacteria, without irradiation. In order to quantify only adsorption, ABT and FeNTA adsorption were assayed in independent experiments on this material (concentrations tested: ABT, $0.5 \mathrm{mM}$ and FeNTA, $1 \mathrm{mM}$ ). The concentration of ABT in the incubation medium was measured by HPLC after SPE treatment while total iron was measured directly by spectrophotometry. Results are reported in Table 1. ABT was rapidly adsorbed on alginate beads: $8 \%(0.04 \mathrm{mM})$ disappeared from the medium within 30 minutes. Equilibrium between adsorbed and free ABT was then reached under the conditions used. On the contrary, no adsorption of iron was observed. However, with free and Ca-alginate immobilized cells (IC), iron concentration decreased by about $20 \%$ in the solution. This result could be attributed to a phenomenon of FeNTA decomplexation observed at $\mathrm{pH}$ higher than 7.0 (Abida, 2005), which was the $\mathrm{pH}$ reached in the presence of cells. Under these conditions, free iron precipitates.

\section{Table 1.}

Adsorption of ABT and iron on alginate beads (absence of light and of bacteria). Concentrations are measured in the incubation medium by HPLC (ABT) and by spectrophotometry (total iron).

\begin{tabular}{|c|c|c|c|c|c|c|c|c|c|}
\hline & \multicolumn{8}{|c|}{ Time (h) } \\
\hline & & T0 & 0.5 & 1 & 2 & 3 & 21 & 77 & 145 \\
\hline No alginate beads & ABT (mM) & 0.50 & 0.48 & 0.48 & 0.49 & 0.49 & 0.48 & 0.49 & 0.50 \\
\hline Alginate beads & & 0.50 & 0.46 & 0.45 & 0.44 & 0.44 & 0.45 & 0.44 & 0.44 \\
\hline No alginate beads & Total iron $(\mathrm{mM})$ & 1.00 & 0.82 & 0.76 & 0.76 & 0.76 & 0.83 & 0.85 & 0.79 \\
\hline Alginate beads & & 1.00 & 0.90 & 0.89 & 0.88 & 0.87 & 0.75 & 0.78 & 0.81 \\
\hline
\end{tabular}

\subsection{Comparison of the degradation processes with free and immobilized cells (IC)}


The various conditions of ABT degradation studied during this work are presented in Table 1 in the Supplementary material. They correspond to different combinations of processes that can occur in the environment: bacteria alone free and immobilized, sunlight alone, presence of iron complexes, combination of various parameters.

\subsubsection{Biodegradation process}

Experiments were carried out to compare both the ABT biodegradation pathway and the efficiency of the process conducted by free and Ca-alginate immobilized $R$. rhodochrous cells. The effect of irradiation was also tested on these two cellular systems in order to assess the potential for protection of the microorganisms by the alginate beads with respect to light.

Table 2 shows the evolution of ABT concentrations measured by HPLC in free and IC systems with or without irradiation. In both systems, the biodegradation of ABT was more efficient in the absence of light, showing that alginate does not in fact protect the cells. Rhodococcus cells are indeed slightly sensitive to light but to a low extent because they produce certain red pigments under irradiation that naturally protect them (data not shown). By considering the adsorption effect of ABT on alginate beads, similar degradation rates were observed in both IC and free cell systems. After $100 \mathrm{~h}$ of incubation, the conversion percentages of ABT were very similar: in the presence of light, $14 \%$ were converted with cells in suspension and 22\% (adsorption considered) with the alginate system; in the absence of light, 28\% and $30 \%$ (adsorption considered), respectively. No 6OH-ABT was observed in irradiated cases. In the absence of irradiation, the concentration of $6 \mathrm{OH}-\mathrm{ABT}$ was similar in both systems.

Table 2 .

Percentages of ABT degradation during biodegradation processes: comparison between IC and free cell systems. Concentrations are measured by HPLC (values between brackets: corrected values with the value of ABT adsorption on alginate beads).

\begin{tabular}{|c|c|c|c|c|c|c|c|c|c|}
\hline & & & T0 (\%) & 0.5 h (\%) & 2 h (\%) & 3 h (\%) & 29 h (\%) & 77h (\%) & $100 \mathrm{~h}(\%)$ \\
\hline Biodegradation & Free cells & Light & 0 & 12 & 14 & 12 & 12 & 16 & 14 \\
\hline & & No light & 0 & 12 & 10 & 8 & 22 & 28 & 28 \\
\hline & Alginate beads & Light & 0 & $20(12)$ & $16(8)$ & $28(20)$ & $22(14)$ & $24(16)$ & $30(22)$ \\
\hline & & No light & 0 & $28(20)$ & $18(10)$ & $26(18)$ & $34(26)$ & $38(30)$ & $38(30)$ \\
\hline
\end{tabular}

\subsubsection{Photodegradation process (FeNTA \pm light)}

The effect of alginate beads (without cells) on the photodegradation process induced by FeNTA was assessed with or without irradiation. In both systems, ABT was almost not degraded in the absence of light. The slight decrease of ABT concentration resulted only from its adsorption on alginate beads. Under irradiation, evolutions of ABT concentration with time were similar in both systems. After $100 \mathrm{~h}$ of irradiation, $46 \%$ of $\mathrm{ABT}$ was photodegraded in solution versus $38 \%$ (corrected value) with alginate beads.

Moreover, the presence of alginate beads did not modify the photodegradation pathway (the same intermediates were observed). This result is important for understanding combined photo-biodegradation processes conducted with Ca-alginate embedded cells.

\subsubsection{Combined bio- and/or photodegradation process}

As mentioned in the first part of the results, the light had no real effect on the combined processes and only experiments without light are presented. The combined process consisted of assays with FeNTA and $R$. rhodochrous cells. The most important effect was due to the presence of FeNTA which greatly accelerates the ABT degradation compared with bacteria alone. After $29 \mathrm{~h}$, in the absence of light, $22 \%$ and 26\% (adsorption considered) (Table 2) of ABT was converted with the biodegradation process for the suspension cell and the IC systems, respectively, and 96\% and 76\% (adsorption considered) with the combined process (Fig. 4A). This strong effect of FeNTA was observed previously for free cells (Bunescu et al., 2008a) and is confirmed here for embedded cells. The degradation in the free cell system with FeNTA is slightly more efficient than in alginate beads. Fig. 4B shows, for free cell system, a rapid production of $6 \mathrm{OH}-\mathrm{ABT}$, reaching $0.05 \mathrm{mM}$ after $3 \mathrm{~h}$, followed by a complete disappearance after $145 \mathrm{~h}$. In the IC system $6 \mathrm{OH}-\mathrm{ABT}$ is also produced but more slowly. Its concentration is lower; the kinetics appears to be slowed down with encapsulated cells. Fig. 4C shows the same evolution tendencies for 
4OH-ABT. Concerning total iron titration presented in Fig. 4D, in both cases, a regular decrease is observed. Nevertheless much more total iron is consumed in the IC system although the ABT degradation is less efficient $(0.08 \mathrm{mM}$ in IC system versus $0.37 \mathrm{mM}$ in free cells after $145 \mathrm{~h}$ of incubation). A breaking-up of alginate beads is observed with time: interactions between the units of sugar and the calcium cation responsible for the gelling are probably replaced by interactions with iron cation. This exchange of cation makes iron unavailable in alginate experiments and explains the difference of total iron concentrations between the two systems (Sreeram et al., 2004).
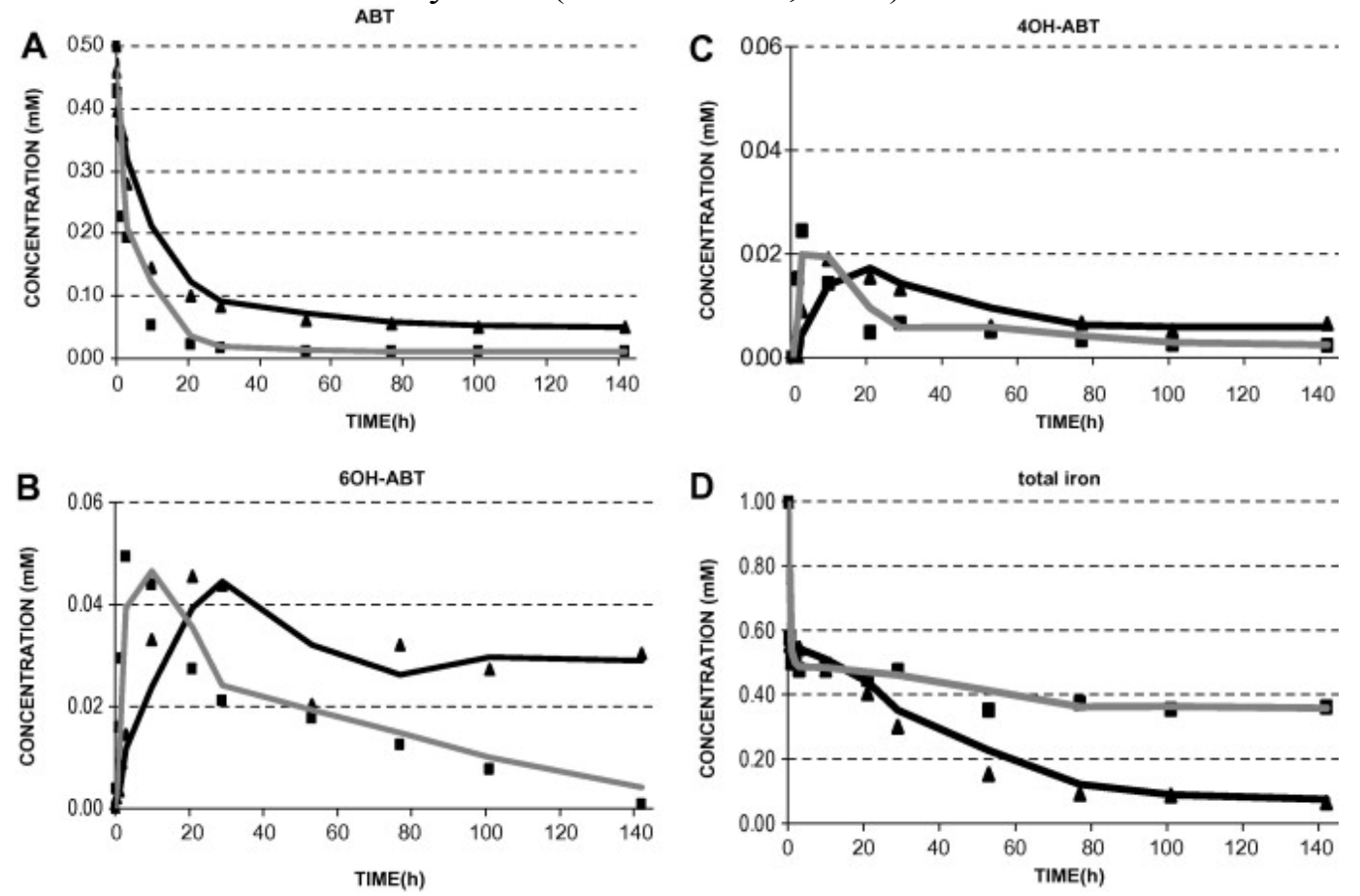

Fig. 4. ABT degradation by the combined process (ABT: $0.5 \mathrm{mM}$, FeNTA: $1 \mathrm{mM}$, no light): comparison between free suspended cells and IC systems. $(\boldsymbol{\Lambda},-)$ immobilized bacteria; $(\mathbf{\square}$, (A), the metabolite 6OH-ABT (B), the metabolite 4OH-ABT (C) and total iron (D).

\section{Discussion and conclusion}

In this paper, the degradation of $\mathrm{ABT}$ by free and Ca-alginate immobilized $R$. rhodochrous cells was investigated, and the two systems compared. This comparison required the development of an SPE procedure to eliminate alginate from the incubation samples. Coupled with a 96-well microtiter plate, this protocol allowed large series of analyses. Because alginate is one of the most frequent matrices used to entrap cells, this analytical technique can be useful for other studies.

The first important result of this work is that ABT degradation follows the same pathway in systems containing alginate beads or not, with the same intermediates: $6 \mathrm{OH}-\mathrm{ABT}$ and $4 \mathrm{OH}-\mathrm{ABT}$ in the photodegradation and combined processes; $6 \mathrm{OH}-\mathrm{ABT}$ in the biodegradation process. Considering the small adsorption (8\%) of ABT on Ca-alginate gel, the efficiency of ABT degradation in the different systems is comparable. However we noticed a slightly slower degradation rate in the presence of alginate beads. This is not due to a phenomenon of co-metabolism with alginate since we have shown that $R$. rhodochrous does not use alginate as a carbon source. In addition we proved, using in vivo ${ }^{31} \mathrm{P} \mathrm{NMR}$, that free and immobilized cells had a similar energetic status. Clearly the Ca-alginate matrix had no negative effect on $R$. rhodochrous metabolism which could have been responsible for the small decrease of degradation efficiency. We suggest that a slightly restricted diffusion of the xenobiotic through the Caalginate matrix could occur. Also, iron could partly replace Ca in the gel matrix ([Min and Hering, 1998] and [Sreeram et al., 2004]) avoiding its uptake by the bacteria and thus the activation of bacterial degradative enzymes. All these results show that mechanisms observed with free cells can be extrapolated to entrapped cells, i.e. conditions much closer to those usually encountered in the environment.

Finally, the major result is that the positive effect of FeNTA on ABT degradation is observed with immobilized cells in a similar way as was shown with free cells. This feature is very important with respect to the environmental context. Indeed FeNTA is considered as a good model of iron natural matter complexes existing in surface waters. Moreover, NTA, used as a domestic detergent, is present in large 
quantities in water treatment plants (Egli, 2001). Thus, FeNTA could activate bacteria which can be in the form of immobilized cells (biofilms) in this environment (Junter and Jouenne, 2004).

\section{Acknowledgements}

We would like to thank the INTAS for its financial support and the Région d'Auvergne for C. Chorao's PhD fellowship. We greatly acknowledge Elisabeth Gout and Richard Bligny (CEA Grenoble, France) for their help in setting-up the perfusion system for in vivo NMR experiments. We would like to thank Elodie Cano for microbiological assistance and Maria Matulova for her NMR study on alginate degradation by R. rhodochrous.

\section{References}

Abida, 2005 Abida, O., 2005. Thesis for Université Blaise Pascal, Serial No. D.U: 1635, Clermont-Ferrand (France).

Besse et al., 2001 P. Besse, B. Combourieu, G. Boyse, M. Sancelme, H. De Wever and A.M. Delort, Long range ${ }^{1}$ H- ${ }^{15}$ N heteronuclear shift correlation at natural abundance: a tool to study benzothiazole biodegradation by two Rhodococcus strains, Appl. Environ. Microb. 67 (2001), pp. 1412-1417.

Brownlee et al., 1992 B.G. Brownlee, J.H. Carey, G.A. Mac-Innis and I.T. Pellizzari, Aquatic environmental chemistry of 2(thiocyanomethylthio)benzothiazole and related benzothiazoles, Environ. Toxicol. Chem. 11 (1992), pp. $1153-1168$.

Bryson et al., 1996 H. Bryson, B. Fulton and P. Benfield, Riluzole: a review of its pharmacodynamic and pharmacokinetic properties and therapeutic potential in amyotrophic lateral sclerosis, Drugs 52 (1996), pp. 549-563.

Bunescu et al., 2008a A. Bunescu, P. Besse-Hoggan, M. Sancelme, G. Mailhot and A.M. Delort, Comparison of microbial and photochemical process and their combination for degradation of 2-aminobenzothiazole, Appl. Environ. Microb. 74 (2008), pp. 2976-2984.

Bunescu et al., 2008b A. Bunescu, P. Besse-Hoggan, M. Sancelme, G. Mailhot and A.-M. Delort, Fate of the nitrilotriacetic acid-Fe(III) complex (FeNTA) during photodegradation and biodegradation by Rhodococcus rhodochrous, Appl. Environ. Microb. 74 (2008), pp. 6320-6326.

De Wever et al., 1997 H. De Wever, S. De Cort, I. Noots and H. Verachtert, Isolation and characterization of Rhodococcus rhodochrous for the degradation of the wastewater component 2-hydroxybenzothiazole, Appl. Microbiol. Biot. 47 (1997), pp. 458-461.

De Wever et al., 1998 H. De Wever, K. Vereecken, A. Stolz and H. Verachtert, Initial transformations in the biodegradation of benzothiazoles by Rhodococcus isolates, Appl. Environ. Microb. 64 (1998), pp. 3270-3274.

De Wever et al., 2007 H. De Wever, S. Weiss, T. Reemtsma, J. Vereecken, J. Müller, T. Knepper, O. Rörden, S. Gonzalez, D. Barcelo and M.D. Hernando, Comparison of sulfonated and other micropollutants removal in membrane bioreactor and conventional wastewater treatment, Water Res. 41 (2007), pp. 935-945.

Dubey et al., 2006 R. Dubey, P.K. Shrivastava, P.K. Basniwal, S. Bhattacharya and N.S. Moorthy, 2-(4Aminophenyl)benzothiazole: a potent and selective pharmacophore with novel mechanistic action towards various tumour cell lines, Mini-Rev. Med. Chem. 6 (2006), pp. 633-637.

Egli, 2001 T. Egli, Biodegradation of metal-complexing aminopolycarboxylic acids, J. Biosci. Bioeng. 92 (2001), pp. 89-97. Gaja and Knapp, 1997 M.A. Gaja and J.S. Knapp, The microbial degradation of benzothiazoles, J. Appl. Microbiol. 83 (1997), pp. 327-334.

Ghosh et al., 2003 P. Ghosh, S. Katare, P. Patkar, J.M. Caruthers, V. Venkatasubramanian and K.A. Walker, Sulfur vulcanization of natural rubber for benzothiazole accelerated formulations: from reaction mechanisms to a rational kinetic model, Rubber Chem. Technol. 76 (2003), pp. 592-693.

Grivet and Delort, 2008 J.P. Grivet and A.M. Delort, NMR for microbiology: in vivo and in situ applications, Prog. Nucl. Mag. Res. Sp. (2008)

Haroune et al., 2002 N. Haroune, B. Combourieu, P. Besse, M. Sancelme, T. Reemtsma, A. Kloepfer, A. Diab, J.S. Knapp, S. Baumberg and A.M. Delort, Benzothiazole degradation by Rhodococcus pyridinovorans strain PA: evidence of a catechol 1,2dioxygenase activity, Appl. Environ. Microb. 68 (2002), pp. 6114-6120.

Haroune et al., 2004 N. Haroune, B. Combourieu, P. Besse, M. Sancelme, A. Kloepfer, H. De Wever and A.M. Delort, Metabolism of 2-mercaptobenzothiazole by Rhodococcus rhodochrous, Appl. Environ. Microb. 70 (2004), pp. 6315-6319.

Junter and Jouenne, 2004 G.A. Junter and T. Jouenne, Immobilized viable microbial cells: from the process to the proteome... Or the cart before the horse, Biotechnol. Adv. 22 (2004), pp. 633-658.

Kitamikado et al., 1992 M. Kitamikado, T. Chao-Huang, K. Yamaguchi and T. Nakamura, Two types of bacterial alginate lyases, Appl. Environ. Microb. 58 (1992), pp. 2474-2478.

Kloepfer et al., 2004 A. Kloepfer, R. Gnirss, M. Jekel and T. Reemtsma, Occurrence of benzothiazoles in municipal wastewater and their fate in biological treatment, Water Sci. Technol. 50 (2004), pp. 203-208.

Kloepfer et al., 2005 A. Kloepfer, M. Jekel and T. Reemtsma, Occurrence, sources, and fate of benzothiazoles in municipal wastewater treatment plants, Environ. Sci. Technol. 39 (2005), pp. 3792-3798.

Lacomblez et al., 1996 L. Lacomblez, G. Bensimon, P.N. Leigh, P.N. Guillet and V. Meininger, Dose-ranging of riluzole and amyotrophic lateral sclerosis, Lancet 347 (1996), pp. 1425-1431.

Lohmeier-Vogel et al., 2004 E.M. Lohmeier-Vogel, S. Ung and R.J. Turner, In vivo ${ }^{31} \mathrm{P}$ nuclear magnetic resonance investigation of tellurite toxicity in Escherichia coli, Appl. Environ. Microb. 70 (2004), pp. 7342-7347.

Mainprize et al., 1976 J. Mainprize, J.S. Knapp and A.G. Callely, The fate of benzothiazole-2-sulfonic acid in biologically treated industrial effluents, J. Appl. Bacteriol. 40 (1976), pp. 285-291. 
Min and Hering, 1998 J.H. Min and J.G. Hering, Arsenate sorption by Fe(III)-doped alginate gels, Water Res. 32 (1998), pp. 1544-1552.

Mukerjee-Dhar et al., 1998 G. Mukerjee-Dhar, M. Shimura and K. Kimbara, Degradation of polychlorinated biphenyl by cells of Rhodococcus opacus strain TSP203 immobilized in alginate and in solution, Enzyme. Microb. Tech. 23 (1998), pp. 34-41. Naito et al., 2001 M. Naito, T. Kawamoto and K. Fujino, Long-term repeated biodesulfurization by immobilized Rhodococcus erythropolis KA2-5-1 cells, Appl. Microbiol. Biot. 55 (2001), pp. 374-378.

Pai et al., 1995 S.L. Pai, Y.L. Hsu, N.M. Chong, C.S. Sheu and C.H. Chen, Continuous degradation of phenol by Rhodococcus sp. immobilized on granular activated carbon and calcium alginate, Bioresource Technol. 51 (1995), pp. 37-42.

Reemtsma et al., 2006 T. Reemtsma, S. Weiss, J. Mueller, M. Petrovic, S. Gonzalez, D. Barcelo, F. Ventura and T.P. Knepper, Polar pollutants entry into the water cycle by municipal wastewater: a European perspective, Environ. Sci. Technol. 40 (2006), pp. 5451-5458.

Sreeram et al., 2004 K.J. Sreeram, H.Y. Shrivastava and B. Unni Nair, Studies on the nature of interaction of iron(III) with alginates, Biochim. Biophys. Acta 1670 (2004), pp. 121-125.

Stookey, 1970 L. Stookey, Ferrozine - a new spectrophotometric reagent for iron, Anal. Chem. 42 (1970), pp. 779-781. 